\title{
ANALISIS KARAKTERISTIK MARSHALL CAMPURAN HOT ROLLED SHEET WEARING COURSE (HRS-WC) MENGGUNAKAN BAHAN TAMBAH KARET PADAT
}

\author{
Rasyid Ridha ${ }^{1}$, Salonten ${ }^{2}$ dan Murniati ${ }^{3}$ \\ ${ }^{123}$ Program Studi Teknik Sipil, Fakultas Teknik, Universitas Palangka Raya \\ E-mail: ibrahimsemut95@gmail.com ${ }^{1}$, salonten@jts.upr.ac.id ${ }^{2}$, \\ dan murniati-upr@eng.ac.id ${ }^{3} /{ }^{1}$ P.+6281256637290 1
}

\begin{abstract}
ABSTRAK
Kinerja campuran agregat aspal pada konstruksi perkerasan jalan dicoba untuk ditingkatkan dengan cara memodifikasi campuran aspal sehingga didapatkan perubahan sifat campuran aspal, khususnya pada penetrasi dan titik lembeknya dengan menambahkan bahan tambahan karet padat sehingga diharapkan pada penelitian ini bisa mengurangi kepekaan aspal terhadap temperatur dan keelastisannya. Penelitian ini dilakukan untuk mengetahui sejauhmana manfaat penggunaan karet sebagai bahan tambahan pada campuran aspal panas yang diharapkan penggunaannya dapat meningkatkan mutu perkerasan lentur jalan raya. Pengujian Marshall dengan penambahan karet dengan variasi kadar bahan tambah $2 \%, 4 \%, 6 \%, 8 \%$ dan $10 \%$ terhadap berat aspal yang diperoleh dari KAO pada benda uji, hasil parameter Marshall memenuhi spesifikasi yang ada. Dari hasil evaluasi sifat karakteristik Marshall diperoleh rentang penambahan kadar karet $0 \%$ hingga 7,9\%, campuran memenuhi semua spesifikasi yang ditentukan. Kadar penambahan plastik optimum ditetapkan dari nilai parameter Marshall yang memenuhi semua persyaratan spesifikasi dan dilihat dari nilai stabilitas tertinggi, yaitu pada kadar penambahan karet sebesar 7,90\%. Penambahan karet sebesar $7,90 \%$ dari berat aspal menghasilkan nilai stabilitas naik 9,98\% dari nilai stabilitas campuran tanpa menggunakan bahan tambah karet yaitu mengalami kenaikan sebesar $93 \mathrm{~kg}$, nilai flow naik sebesar $0,27 \mathrm{~mm}$, rongga dalam campuran (VIM) turun sebesar $0,80 \%$, rongga terisi aspal (VFB) naik sebesar 4,20\% dan hasil bagi Marshall (Marshall Quotient) naik sebesar $11 \mathrm{~kg} / \mathrm{mm}$.
\end{abstract}

Kata Kunci: Aspal Karet, Hot Rolled Sheet Wearing Coaurse, Kadar Aspal Optimum.

ABSTRACT
The performance of the asphalt aggregate mixture in road pavement construction
is tried to be improved by modifying the asphalt mixture so that changes in the
properties of the asphalt mixture are obtained, especially in its penetration and
softening point by adding solid rubber additives. This study was conducted to
determine the extent to which the benefits of using rubber as an additive in hot
asphalt mixtures are expected to improve the quality of flexible pavements.
Marshall testing with the addition of rubber with variations in the content of
added ingredients $2 \%, 4 \%, 6 \%, 8 \%$ and $10 \%$ of the asphalt weight obtained from
KAO on the test object, the Marshall parameter results meet the existing
specifications. From the results of the evaluation of Marshall characteristics, the
range of addition of rubber content was $0 \%$ to $7.9 \%$, the mixture met all the
specified specifications. The optimum level of plastic addition is determined from
the Marshall parameter value that meets all the specifications and is seen from 
JURNAL KACAPURI

JURNAL KEILMUAN TEKNIK SIPIL

Volume 4 Nomor 2 Edisi Desember 2021

the highest stability value, namely the rubber addition content of $7.90 \%$. The addition of rubber of $7.90 \%$ of the asphalt weight resulted in an increase of $9.98 \%$ of the stability value of the mixture without the use of added rubber, which increased by $93 \mathrm{~kg}$, the flow value increased by $0.27 \mathrm{~mm}$, the cavity in the mixture (VIM) decreased. by $0.80 \%$, asphalt filled voids (VFB) increased by $4.20 \%$ and Marshall quotient (Marshall Quotient) increased by $11 \mathrm{~kg} / \mathrm{mm}$.

Keywords : Rubber Asphalt, Hot Rolled Sheet Wearing Course, optimum bitumen content.

\section{PENDAHULUAN}

\section{Latar Belakang}

Pembangunan infrastruktur jalan merupakan nadi bagi mobilitas masyarakat sebagai penunjang transportasi darat. Pembangunan dan pemeliharaan infrastruktur jalan diharapkan menjadi prioritas pemerintah mengingat semakin besar jumlah penduduk. Kondisi tersebut harus didukung oleh konstruksi jalan yang berkualitas, terutama lapis perkerasan guna memberikan kenyamanan dan keamanan bagi pengguna jalan. Banyak cara yang dapat dilakukan untuk meningkatkan kualitas perkerasan, salah satu caranya yaitu dengan memodifikasi sifat-sifat fisik aspal khususnya pada penetrasi dan titik lembeknya dengan menggunakan bahan tambahan sehingga diharapkan bisa mengurangi kepekaan aspal terhadap temperatur dan keelastisannya. Karet padat jenis lump adalah bahan tambahan untuk campuran Hot Rolled Sheet Wearing Course (HRS-WC), bahan ini berasal dari karet alam yang telah dicetak dalam bentuk gumpalan, diharapkan dengan menambahkan campuran karet padat jenis lump kedalam konstruksi perkerasan jalan dapat memberikan banyak keuntungan, diantaranya permukaan perkerasan menjadi lebih tahan lama, tahan terhadap retakan akibat lendutan yang berlebihan serta retakan akibat kelelahan bahan, meningkatkan daya cengkeram permukaan akibat pengereman dan mengurangi kebisingan akibat gesekan ban roda dengan permukaan perkerasan. Indonesia merupakan negara beriklim tropis yang menyebabkan suhu dan cuaca yang selalu berubah-ubah sehingga menjadi salah satu penyebab sering terjadi kerusakan dini pada lapisan perkerasan. Atas dasar tersebut barangkali perlu peningkatan mutu campuran aspal yang baik. Peningkatan tersebut dilakukan dengan cara penambahan bahan karet padat pada proses pencampuran aspal dan material di Asphalt Mixing Plant (AMP) yang dikenal juga dengan sebutan aspal modifikasi. Penggunaan karet padat diharapkan mampu meningkatkan mutu campuran beraspal, dimana fungsi karet pada campuran dapat berperan sebagai bahan stabilitas aspal.

\section{Tujuan Penelitian}

Dalam penelitian ini bertujuan untuk mengetahui sifat-sifat fisik agregat, kadar bahan tambah optimum dari campuran, dan nilai karakteristik Marshall yang dihasilkan dengan menggunakan bahan tambah karet padat dengan variasi kadar bahan tambah yang direncanakan pada campuran Hot Rolled Sheet Wearing Course (HRS-WC).

\section{METODE PENELITIAN}

\section{1) Umum}

Penelitian ini menggunakan metode uji laboratorium, yaitu untuk menganalisis 
JURNAL KACAPURI

JURNAL KEILMUAN TEKNIK SIPIL

Volume 4 Nomor 2 Edisi Desember 2021

penggunaaan karet alam padat sebagai bahan tambah pada aspal dalam lapisan Lataston Lapis Aus (Hot Rolled Sheet-Wearing Course). Dalam penelitian di laboratorium diadakan pengamatan dan pemeriksaan terhadap proporsi campuran Lataston Lapis Aus (Hot Rolled Sheet-Wearing Course) yang memenuhi spesifikasi. Data yang dihasilkan digunakan untuk perancangan campuran, selanjutnya dibuat benda uji (briket) untuk dilakukan uji Marshall sehingga diketahui karakteristik campuran tersebut.

\section{2) Lokasi dan Teknik Pengambilan Sampel}

Pengambilan material berupa agregat ex. Palu pada stockfile yang berada di Asphalt Mixing Plant (AMP) PT. Kalindra Utama Jalan Trans Kalimantan Palangka Raya-Kuala Kurun Desa Bahu Palawa Kabupaten Pulang Pisau.

\section{3) Metode Pengambilan Data}

Pengambilan data dilakukan dengan membuat briket/benda uji sebanyak 30 buah. Benda uji tersebut dibagi dalam 2 kali percobaan. Percobaan pertama dibuat 15 briket/benda uji yang terdiri dari 1 macam komposisi terbaik yang mendekati spesifikasi dengan 5 variasi kadar aspal. Tiap variasi kadar aspal dibuat 3 buah briket/benda uji yang kemudian hasilnya dirata-ratakan untuk kemudian didapatkan kadar Aspal Optimum (KAO). Percobaan kedua, Kadar Aspal Optimum (KAO) yang didapat pada percobaan pertama dipergunakan sebagai kadar aspal untuk memuat 15 buah briket/benda uji, yang terdiri dari 5 variasi persentase berat karet padat terhadap berat aspal yang diperoleh dari Kadar Aspal Optimum (KAO), yaitu berat karet padat sebagai bahan tambah persentase $2 \%$, $4 \%, 6 \%, 8 \%$ dan $10 \%$. Tiap variasi persentase berat karet dibuat 3 buah briket/benda uji. Pembuatan dan pengujian briket/benda uji ini dilakukan di Laboratorium Jalan Raya Fakultas Teknik Universitas Palangka Raya.

\section{HASIL DAN PEMBAHASAN}

Pemeriksaan gradasi agregat kasar, abu batu dan pasir dilakukan dengan uji analisa saringan yang hasilnya dapat dilihat pada Tabel 1 berikut ini

Tabel 1. Hasil Analisa Saringan Masing-masing Agregat

\begin{tabular}{|c|c|c|c|c|}
\hline \multirow{2}{*}{ No. Saringan } & \multicolumn{3}{c|}{ Persentase Lolos Saringan (\%) } \\
\cline { 3 - 5 } \multicolumn{2}{|c|}{ Eks. Palu } & Eks. Tangkiling \\
\hline Inch & $\mathrm{mm}$ & Agregat Kasar (CA) & Abu Batu (FA) & Pasir (SA) \\
\hline$\# 3 / 4$ & 19 & 100,00 & 100,00 & 100,00 \\
\hline$\# 1 / 2$ & 12,7 & 74,63 & 100,00 & 100,00 \\
\hline$\# 3 / 8$ & 9,5 & 30,40 & 100,00 & 100,00 \\
\hline No.8 & 2,36 & 5,50 & 84,82 & 94,93 \\
\hline No.30 & 0,60 & 2,37 & 56,71 & 58,83 \\
\hline No.200 & 0,075 & 0,77 & 13,06 & 11,73 \\
\hline
\end{tabular}

Sumber: Hasil Pemeriksaan (2021)

Pemeriksaan sifat-sifat fisik agregat yang berupa pemeriksaan berat jenis dan penyerapan agregat kasar dan agregat halus, pemeriksaan keausan (Abrasi) agregat kasar dan pemeriksaan kadar lempung (sand equivalent) dapat dilihat pada Tabel 2 berikut ini. 
JURNAL KACAPURI

JURNAL KEILMUAN TEKNIK SIPIL

Volume 4 Nomor 2 Edisi Desember 2021

Tabel 2. Hasil Pemeriksaan Sifat Fisik Masing-masing Agregat

\begin{tabular}{|c|c|c|c|}
\hline \multirow{2}{*}{ Pemeriksaan } & \multicolumn{2}{|c|}{ Eks. Palu } & \multirow{2}{*}{ Pasir Tangkiling } \\
\hline & Agregat Kasar & Abu Batu & \\
\hline Berat Jenis $\left(\mathrm{gram} / \mathrm{cm}^{3}\right)$ & 2,654 & 2,531 & 2,507 \\
\hline $\begin{array}{l}\text { Berat Jenis Kering Permukaan / } \\
\text { SSD }\left(\text { gram } / \mathrm{cm}^{3}\right)\end{array}$ & 2,691 & 2,578 & 2,556 \\
\hline Berat Jenis Semu $\left(\mathrm{gram} / \mathrm{cm}^{3}\right)$ & 2,758 & 2,654 & 2,636 \\
\hline Penyerapan $(\%)$ & 1,430 & 1,834 & 1,972 \\
\hline Keausan / Abrasi (\%) & 23,450 & - & - \\
\hline Sand Equivalent (\%) & - & - & 64,83 \\
\hline
\end{tabular}

Sumber: Hasil Pemeriksaan (2021)

Perencanaan campuran menggunakan metode Asphalt Institute dan perhitungan penggabungan agregat menggunakan cara diagonal. Grafik metode diagonal dapat dilihat pada Gambar 1 dan hasil perhitungan pada komposisi ini dapat dilihat pada Tabel 3 di bawah ini.

Tabel 3. Hasil Perhitungan Gradasi Gabungan Cara Diagonal

\begin{tabular}{|c|c|c|c|c|c|c|c|c|c|}
\hline \multicolumn{2}{|c|}{ No. Saringan } & \multicolumn{2}{|c|}{ Agregat Kasar (CA) } & \multicolumn{2}{c|}{ Abu Batu (FA) } & \multicolumn{2}{c|}{ Pasir (SA) } & $\begin{array}{c}\text { Total } \\
\text { Kombinasi }\end{array}$ & \multirow{2}{*}{ Spesifikasi } \\
\hline inch & $\mathrm{mm}$ & $100 \%$ & $34 \%$ & $100 \%$ & $26 \%$ & $100 \%$ & $40 \%$ & \\
\hline$\# 3 / 4$ & 19,0 & 100,00 & 34,00 & 100,00 & 26,00 & 100,00 & 40,00 & 100,00 & 100 \\
\hline$\# 1 / 2$ & 12,7 & 74,63 & 25,38 & 100,00 & 26,00 & 100,00 & 40,00 & 91,38 & $90-100$ \\
\hline$\# 3 / 8$ & 9,5 & 30,40 & 10,34 & 100,00 & 26,00 & 100,00 & 40,00 & 76,34 & $75-85$ \\
\hline No.8 & 2,36 & 5,50 & 1,87 & 84,77 & 22,04 & 94,93 & 37,97 & 61,88 & $50-72$ \\
\hline No.30 & 0,600 & 2,37 & 0,80 & 56,57 & 14,71 & 58,83 & 23,53 & 39,05 & $35-60$ \\
\hline No.200 & 0,075 & 0,77 & 0,26 & 12,77 & 3,32 & 11,73 & 4,69 & 8,27 & $6-10$ \\
\hline
\end{tabular}

Sumber: Hasil Perhitungan (2021)

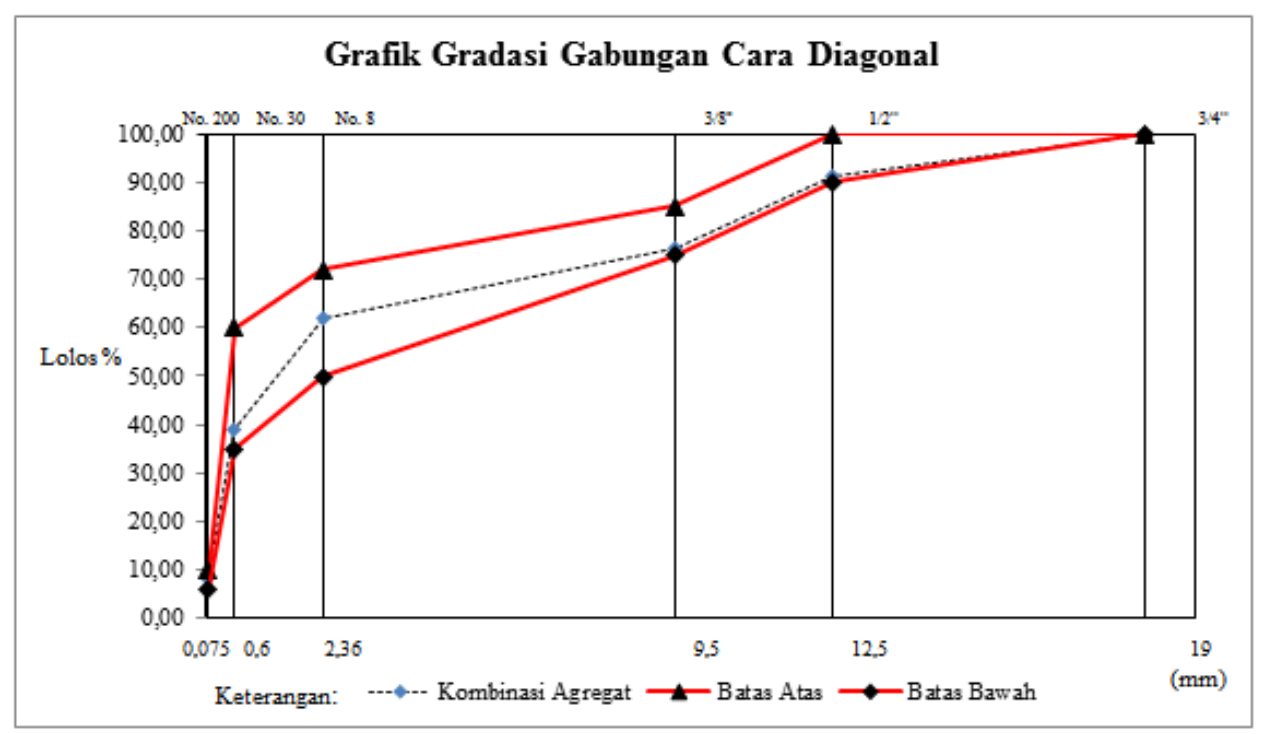

Gambar 1 Grafik Gradasi Gabungan Cara Diagonal

Selanjutnya hasil perhitungan komposisi gradasi agregat gabungan dengan cara diagonal yang sudah diperoleh dikontrol menggunakan cara coba-coba (Trial and Error). Hasil perhitungan untuk proporsi campuran cara coba-coba (Trial and Error) dapat dilihat pada Tabel 4 dibawah ini, dan untuk lebih lengkapnya dapat dilihat pada Gambar 2. 
JURNAL KACAPURI

JURNAL KEILMUAN TEKNIK SIPIL

Volume 4 Nomor 2 Edisi Desember 2021

Tabel 4. Hasil Perhitungan Gradasi Gabungan Cara Trial and Error

\begin{tabular}{|c|c|c|c|c|c|c|c|c|c|}
\hline \multicolumn{2}{|c|}{ No. Saringan } & \multicolumn{2}{|c|}{ Agregat Kasar (CA) } & \multicolumn{2}{c|}{ Abu Batu (FA) } & \multicolumn{2}{c|}{ Pasir (SA) } & \multirow{2}{*}{$\begin{array}{c}\text { Total } \\
\text { Kombinasi }\end{array}$} & Spesifikasi \\
\cline { 1 - 7 } Inch & $\mathrm{Mm}$ & $100 \%$ & $32 \%$ & $100 \%$ & $34 \%$ & $100 \%$ & $34 \%$ & 100 \\
\hline$\# 3 / 4$ & 19,0 & 100,00 & 32,00 & 100,00 & 34,00 & 100,00 & 34,00 & 100,00 & 100 \\
\hline$\# 1 / 2$ & 12,7 & 74,63 & 23,88 & 100,00 & 34,00 & 100,00 & 34,00 & 91,88 & $90-100$ \\
\hline$\# 3 / 8$ & 9,5 & 30,40 & 9,73 & 100,00 & 34,00 & 100,00 & 34,00 & 77,73 & $75-85$ \\
\hline No.8 & 2,36 & 5,50 & 1,76 & 84,77 & 28,82 & 94,93 & 32,28 & 62,86 & $50-72$ \\
\hline No.30 & 0,600 & 2,37 & 0,76 & 56,57 & 19,23 & 58,83 & 20,00 & 39,99 & $35-60$ \\
\hline No.200 & 0,075 & 0,77 & 0,25 & 12,77 & 4,34 & 11,73 & 3,99 & 8,58 & $6-10$ \\
\hline
\end{tabular}

Sumber: Hasil Perhitungan (2021)

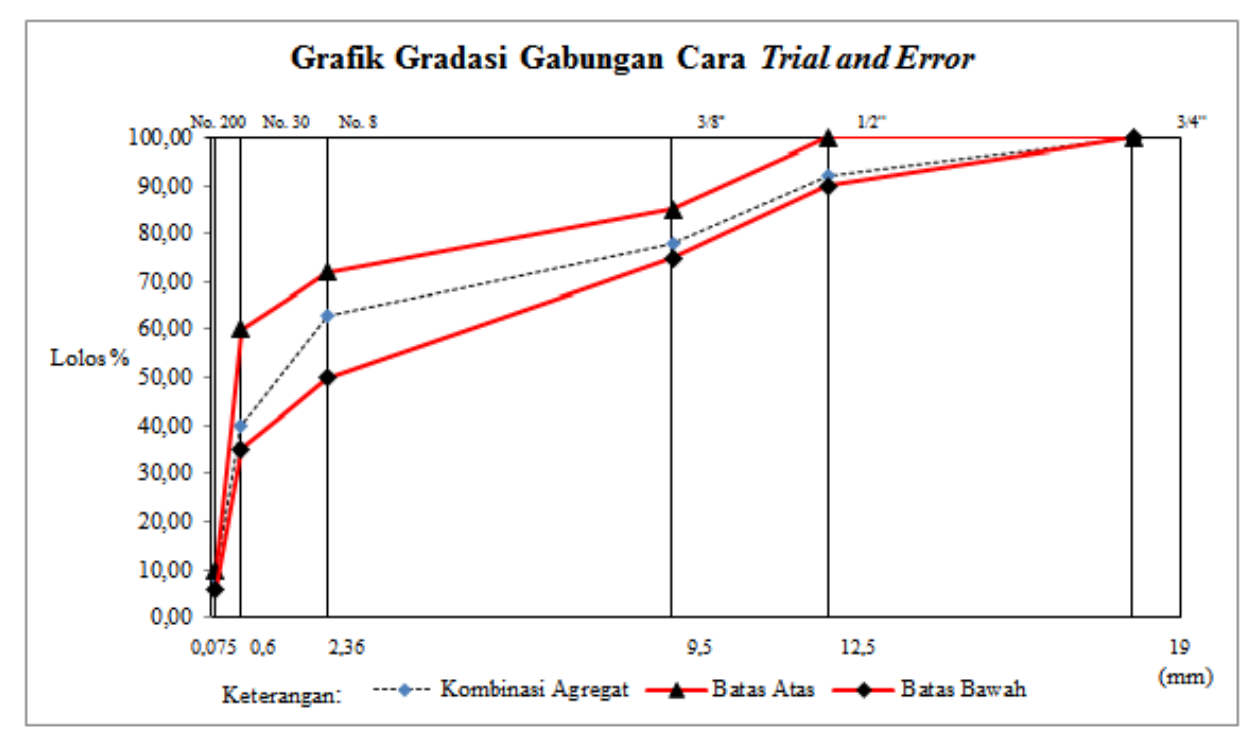

Gambar 2. Grafik Gradasi Gabungan Cara Trial and Error

Hasil perhitungan komposisi campuran berdasarkan cara diagonal dan cara cobacoba (Trial and Error) memenuhi persyaratan gradasi gabungan untuk komposisi campuran Lataston Lapis Aus $(H R S-W C)$ yang direncanakan. Komposisi campuran yang akan digunakan sebagai komposisi untuk pembuatan benda uji adalah hasil perhitungan dari cara coba-coba (Trial and Error) karena nilai total kombinasi cara tersebut lebih mendekati nilai ideal spec. Dari hasil perhitungan komposisi campuran yang sudah didapat, nilai total kombinasi dapat digunakan untuk menentukan perkiraan kadar aspal awal. Perkiraan kadar aspal awal diperoleh dari rumus berikut, yaitu:

$\mathrm{Pb}=0,035(\% \mathrm{CA})+0,045(\% \mathrm{FA})+0,18(\%$ Filler $)+$ Konstanta

Keterangan: $\mathrm{Pb} \quad=$ Kadar aspal

$\mathrm{CA} \quad=$ Agregat kasar (Coarse Aggregate)

FA $\quad=$ Agregat halus (Fine Aggregate)

Filler $\quad=$ Agregat halus lolos saringan No. 200

Konstanta $=2,0-3,0($ diambil nilai konstanta $=2,0)$

Hasil perhitungan cara Trial and Error dapat dilihat pada Tabel 4 diperoleh agregat yang lolos saringan No. 8 sebesar $62,86 \%$. Untuk nilai CA adalah agregat kasar yang tertahan saringan No. 8 ,

maka nilai $\mathrm{CA}=100 \%-62,86 \%=37,14 \%$ 
JURNAL KACAPURI

JURNAL KEILMUAN TEKNIK SIPIL

Volume 4 Nomor 2 Edisi Desember 2021

Sedangkan untuk nilai FA adalah agregat halus lolos saringan No. 8 dan tertahan saringan No. 200. Maka nilai FA $=100 \%-(\% \mathrm{CA}+\%$ Filler $)$

$$
=100 \%-(37,14 \%+8,58 \%)=54,28 \%
$$

Nilai Filler adalah agregat halus lolos saringan No. 200. Dari hasil kombinasi diperoleh agregat yang lolos saringan No. 200 sebesar 8,58\%. Maka nilai Filler $=$ $8,58 \%$

Dengan nilai: $\mathrm{CA}=37,14 \%, \mathrm{FA}=54,28 \%$, Filler $=8,58 \%$

$\mathrm{Pb}=0,035(\% \mathrm{CA})+0,045(\% \mathrm{FA})+0,18(\%$ Filler $)+$ Konstanta

$\mathrm{Pb}=(0,035 \times 37,14)+(0,045 \times 54,28)+(0,18 \times 8,58)+2,0 \mathrm{~Pb}=7,29 \approx 7,5 \%$

Perhitungan kadar aspal tengah yang diperoleh mendekati nilai 7,5\%, yang kemudian diurutkan dua variasi kadar aspal ke bawah dan dua variasi kadar aspal ke atas dengan interval 0,5\%. Dari hasil perhitungan perkiraan kadar aspal diperoleh lima variasi kadar aspal yaitu 6,5\%, 7\%, 7,5\%, 8\%,dan 8,5\%. Persentase terhadap berat total agregat yang digunakan yaitu 1200 gram.

Perhitungan berat material dan aspal dalam campuran berdasarkan proporsi yang telah ditetapkan adalah sebagai berikut:

\section{Contoh perhitungan}

Kadar Aspal 6,5\%

- Agregat Kasar (CA) $32 \%=1200 \times 32 \%$

- Abu Batu (FA)

$34 \%=1200 \times 34 \%$

- Pasir (SA)

$34 \%=1200 \times 34 \%$

\section{Berat Total Agregat}

- Aspal

$$
6,5 \%=\left(\frac{6,5}{(100-6,5)}\right) \times 1200 \quad=83,4 \mathrm{gram}
$$

$$
\begin{array}{ll}
=384 & \text { gram } \\
=408 & \text { gram } \\
=408 & \text { gram }
\end{array}
$$

\begin{tabular}{|c|c|c|c|c|c|c|c|c|c|c|c|c|}
\hline \multicolumn{6}{|c|}{ Berat Total Agregat 1200 gram } & \multirow{3}{*}{$\begin{array}{c}\text { Berat } \\
\text { Total } \\
\text { Agregat } \\
\text { Campuran }\end{array}$} & \multicolumn{5}{|c|}{ Variasi Kadar Aspal } & \multirow{4}{*}{$\begin{array}{c}\text { Kode } \\
\text { Sampel }\end{array}$} \\
\hline \multirow{2}{*}{\multicolumn{2}{|c|}{$\begin{array}{l}\text { Agregat } \\
\text { Kasar }\end{array}$}} & \multirow{2}{*}{\multicolumn{2}{|c|}{ Abu Batu }} & \multirow{2}{*}{\multicolumn{2}{|c|}{ Pasir }} & & $6,5 \%$ & $7,0 \%$ & $7,5 \%$ & $8,0 \%$ & $8,5 \%$ & \\
\hline & & & & & & & \multicolumn{5}{|c|}{$\begin{array}{c}\text { Berat Kadar Aspal Terhadap Total } \\
\text { Campuran }\end{array}$} & \\
\hline$\%$ & gram & $\%$ & $\begin{array}{c}\text { gra } \\
\mathrm{m}\end{array}$ & $\%$ & gram & gram & \multicolumn{5}{|c|}{ Gram } & \\
\hline 32 & 384 & 34 & 408 & 34 & 408 & 1200 & 83,4 & 90,3 & 97,3 & 104,3 & 111,5 & I \\
\hline
\end{tabular}

Berat Total Campuran + Aspal $=1200$ gram + 83,4 gram = 1283,4 gram

Perhitungan rencana berat material dan aspal dapat dilihat pada tabel berikut:

Tabel 5. Rencana Komposisi Campuran

Sumber: Hasil Perhitungan (2021)

Dari hasil perhitungan berat jenis dan penyerapan terhadap total agregat untuk campuran Lataston Lapis Aus (HRS-WC), diperoleh hasil seperti Tabel 5 berikut.

Tabel 5 Perhitungan Berat Jenis dan Penyerapan terhadap Total Agregat:

\begin{tabular}{|c|l|c|c|}
\hline No & \multicolumn{1}{|c|}{ Pemeriksaan } & Satuan & Hasil Perhitungan \\
\hline 1. & Berat Jenis Bulk (GSB) & $\left(\mathrm{gram} / \mathrm{cm}^{3}\right)$ & 2,560 \\
2. & Berat Jenis Semu (GSA) & $\left(\mathrm{gram} / \mathrm{cm}^{3}\right)$ & 2,680 \\
3. & Berat Jenis Efektif (GSE) & $\left(\mathrm{gram} / \mathrm{cm}^{3}\right)$ & 2,620 \\
4. & Penyerapan (Pba) & $\left(\mathrm{gram} / \mathrm{cm}^{3}\right)$ & 0,972 \\
\hline
\end{tabular}

Sumber: Hasil Perhitungan (2021) 
JURNAL KACAPURI

JURNAL KEILMUAN TEKNIK SIPIL

Volume 4 Nomor 2 Edisi Desember 2021

\section{Analisis Hasil Pengujian Marshall dengan Variasi Kadar Aspal}

Tabel 6. Hasil Pengujian Parameter Karakteristik Marshall

\begin{tabular}{|c|c|c|c|c|c|c|}
\hline \multirow{2}{*}{$\begin{array}{c}\text { Kadar } \\
\text { Aspal } \\
(\%)\end{array}$} & \multicolumn{5}{|c|}{ Parameter Karakteristik Marshall } & \multirow[b]{2}{*}{ Keterangan } \\
\hline & $\begin{array}{l}\text { Stabilita } \\
\text { s (kg) }\end{array}$ & $\begin{array}{l}\text { Flow } \\
(\mathrm{mm})\end{array}$ & $\begin{array}{l}\text { VIM } \\
(\%)\end{array}$ & $\begin{array}{l}\text { VFB } \\
(\%)\end{array}$ & $\begin{array}{c}\text { MQ } \\
(\mathrm{kN} / \mathrm{mm})\end{array}$ & \\
\hline 6,5 & 825,926 & 2,80 & 7,42 & 65,57 & 295,217 & $\begin{array}{l}\text { Flow, VIM dan VFB } \\
\text { Tidak Memenuhi }\end{array}$ \\
\hline 7,0 & 906,446 & 3,10 & 5,91 & 72,40 & 293,223 & Memenuhi \\
\hline 7,5 & 973,449 & 3,23 & 4,20 & 80,05 & 300,817 & Memenuhi \\
\hline 8,0 & 860,340 & 3,03 & 3,64 & 83,16 & 283,667 & $\begin{array}{l}\text { VIM Tidak } \\
\text { Memenuhi }\end{array}$ \\
\hline 8,5 & 833,058 & 3,00 & 2,98 & 86,62 & 278,659 & $\begin{array}{l}\text { VIM Tidak } \\
\text { Memenuhi }\end{array}$ \\
\hline $\begin{array}{c}\text { Spesifika } \\
\text { si }\end{array}$ & $>600$ & $>3,00$ & $3-5$ & $>68$ & $>250$ & \\
\hline
\end{tabular}

Sumber: Hasil Pengujian Marshall (2021)

Hasil dari pengujian Marshall I ini menunjukkan bahwa pada kadar aspal 7\% dan $7,5 \%$, campuran aspal tersebut memenuhi spesifikasi terhadap semua parameter Marshall, sedangkan pada kadar aspal 6,5\%, 8,0\% dan 8,5\% beberapa parameter Marshall pada campuran aspal tersebut tidak memenuhi spesifikasi.

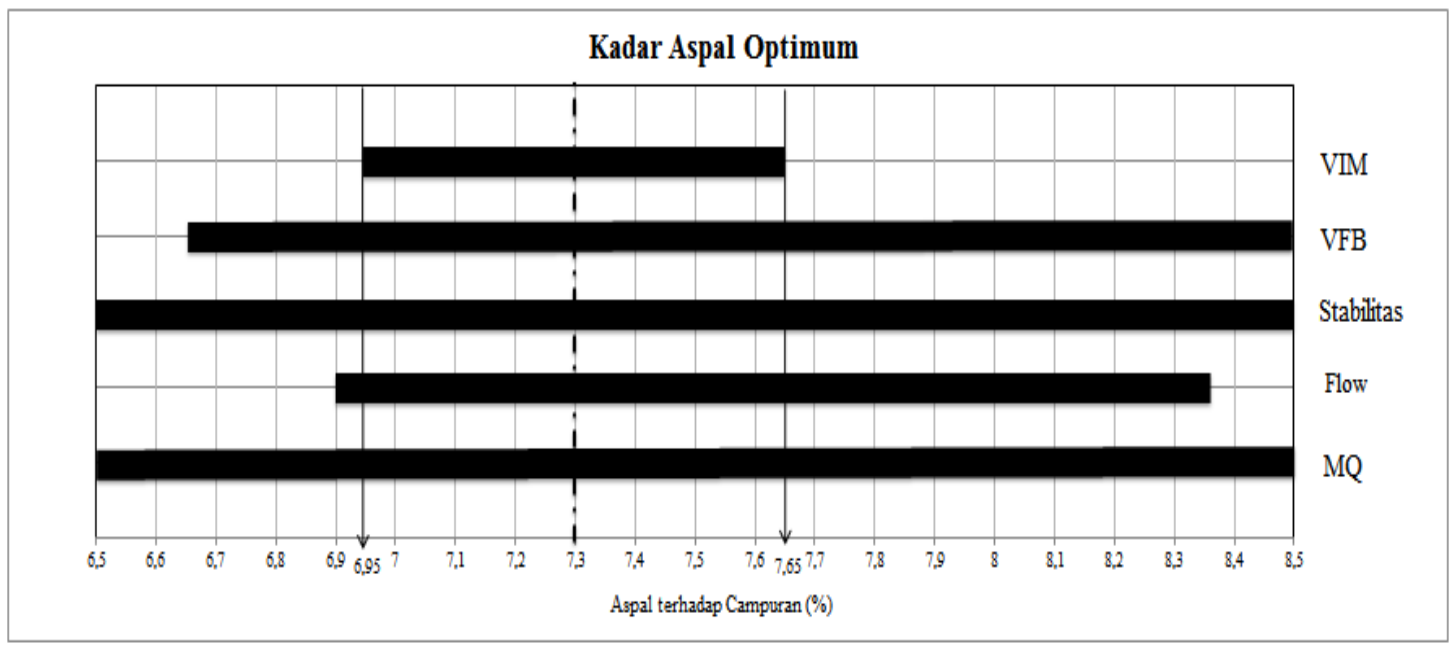

Gambar 3. Grafik Hubungan Nilai Parameter Marshall terhadap Kadar Aspal Optimum (KAO)

Kadar Aspal Optimum

$$
=\frac{6,95+7,65}{2}=7,30 \%
$$

Hasil evaluasi sifat karakteristik Marshall menunjukan bahwa rentang kadar aspal $6,95 \%$ hingga $7,65 \%$ campuran memenuhi semua persyaratan yang ditentukan. Berdasarkan rentang tersebut diambil nilai tengah rentang yaitu 7,30\% sebagai nilai Kadar Aspal Optimum (KAO). Dari hasil pengujian maka didapat hasil nilai parameter Marshall KAO 7,30\% dapat dilihat pada Tabel 7. 
JURNAL KACAPURI

JURNAL KEILMUAN TEKNIK SIPIL

Volume 4 Nomor 2 Edisi Desember 2021

Tabel 7. Nilai Parameter Karakteristik Marshall pada Kadar Aspal Optimum

\begin{tabular}{|c|c|c|c|c|c|c|}
\hline \multirow{2}{*}{$\begin{array}{c}\text { Komposisi } \\
\text { Campuran }\end{array}$} & $\begin{array}{c}\text { KAO } \\
(\%)\end{array}$ & $\begin{array}{c}\text { Stabilitas } \\
(\mathrm{kg})\end{array}$ & $\begin{array}{c}\text { Flow } \\
(\mathrm{mm})\end{array}$ & $\begin{array}{c}\text { Rongga dalam } \\
\text { Campuran }(\%)\end{array}$ & $\begin{array}{c}\text { Rongga } \\
\text { Terisi } \\
\text { Aspal (\%) }\end{array}$ & $\begin{array}{c}\text { Hasil Bagi } \\
\text { Marshall } \\
(\mathrm{kg} / \mathrm{mm})\end{array}$ \\
\hline I & 7,30 & 932,00 & 3,15 & 4,90 & 76,2 & 293,00 \\
\hline Spesifikasi & - & $>600$ & $>3$ & $3-5$ & $>68$ & $>250$ \\
\hline
\end{tabular}

Sumber: Hasil Perhitungan (2021)

Dapat dilihat dari tabel di atas bahwa nilai parameter karakteristik Marshall dari

Kadar Aspal Optimum (KAO) memiliki stabilitas sebesar $932 \mathrm{~kg}$, flow sebesar

$3,15 \mathrm{~mm}$, rongga dalam campuran (VIM) sebesar 4,90\%, rongga terisi aspal

(VFB) sebesar 76,2\% dan hasil bagi Marshall (MQ) sebesar $293 \mathrm{~kg} / \mathrm{mm}$.

Analisis Hasil Pengujian Marshall dengan Bahan Tambah Karet Padat

Tabel 8. Rencana Komposisi Campuran dengan Variasi Bahan Tambah Karet

\begin{tabular}{|c|c|c|c|c|c|c|}
\hline $\begin{array}{c}\text { Berat Total } \\
\text { Agregat } \\
\text { Campuran }\end{array}$ & $\begin{array}{c}\text { Persentase dan } \\
\text { Berat KAO } \\
\text { terhadap Total } \\
\text { Campuran }\end{array}$ & $\begin{array}{c}\text { Persentase } \\
\text { Karet terhadap } \\
\text { Berat Aspal } \\
\text { (KAO) }\end{array}$ & $\begin{array}{c}\text { Berat Karet } \\
\text { terhadap } \\
\text { Berat Aspal } \\
\text { (KAO) }\end{array}$ & $\begin{array}{c}\text { Berat Total } \\
\text { Campuran }\end{array}$ & $\begin{array}{c}\text { Kode } \\
\text { Sampel }\end{array}$ \\
\hline Gram & $\%$ & Gram & $\%$ & Gram & Gram & \\
\hline 1200 & 7,30 & 94,50 & 2,00 & 1,89 & 1296,39 & A \\
\hline 1200 & 7,30 & 94,50 & 4,00 & 3,78 & 1298,28 & B \\
\hline 1200 & 7,30 & 94,50 & 6,00 & 5,67 & 1300,17 & C \\
\hline 1200 & 7,30 & 94,50 & 8,00 & 7,56 & 1302,06 & D \\
\hline 1200 & 7,30 & 94,50 & 10,00 & 9,45 & 1303,95 & E \\
\hline
\end{tabular}

Sumber: Hasil Perhitungan (2021)

Tabel 9. Hasil Pengujian Karakteristik Marshall dengan Bahan Tambah Karet

\begin{tabular}{|c|c|c|c|c|c|c|}
\hline $\begin{array}{c}\text { Kadar Karet } \\
\text { terhadap } \\
\begin{array}{c}\text { Berat Aspal } \\
(\%)\end{array}\end{array}$ & $\begin{array}{c}\text { Stabilitas } \\
(\mathrm{kg})\end{array}$ & $\begin{array}{c}\text { Flow } \\
(\mathrm{mm})\end{array}$ & $\begin{array}{c}\text { VIM } \\
(\%)\end{array}$ & $\begin{array}{c}\text { VFB } \\
(\%)\end{array}$ & $\begin{array}{c}\text { MQ } \\
(\mathrm{kN} / \mathrm{mm})\end{array}$ & \multirow{2}{*}{ Keterangan } \\
\hline 0,0 & 932,000 & 3,15 & 4,90 & 76,20 & 293,000 & Hasil Marshall \\
\hline 2,0 & 968,639 & 3,22 & 4,92 & 76,74 & 301,032 & Memenuhi \\
\hline 4,0 & 995,092 & 3,27 & 4,53 & 78,28 & 303,645 & Memenuhi \\
\hline 6,0 & 998,409 & 3,38 & 4,09 & 80,06 & 294,698 & Memenuhi \\
\hline 8,0 & 1034,066 & 3,38 & 3,88 & 80,91 & 306,013 & $\begin{array}{c}\text { VIM Tidak } \\
\text { Memenuhi }\end{array}$ \\
\hline 10,0 & 1041,198 & 3,48 & 3,93 & 80,64 & 299,151 & $\begin{array}{c}\text { VIMTidak } \\
\text { Memenuhi }\end{array}$ \\
\hline Spesifikasi & $>600$ & $>3,00$ & $3-5$ & $>68$ & $>250$ & \multirow{4}{|c}{} \\
\hline
\end{tabular}

Sumber: Hasil Perhitungan (2021)

Dari hasil pengujian Marshall II ini menunjukan bahwa pada penambahan karet ke dalam campuran pada persentase $2 \%, 4 \%$ dan $6 \%$ terhadap berat aspal dari KAO, campuran aspal tersebut sudah memenuhi Spesifikasi Parameter Marshall pada Spesifikasi Bina Marga (2010) Revisi 3 (tiga). Sedangkan untuk penambahan karet persentase $8 \%$ dan $10 \%$, nilai parameter karakteristik Marshall dari rongga dalam campuran (VIM) tidak memenuhi Spesifikasi. Nilai rongga dalam campuran (VIM) untuk persentase bahan tambah $8 \%$ dan $10 \%$ berturut- 
JURNAL KACAPURI

JURNAL KEILMUAN TEKNIK SIPIL

Volume 4 Nomor 2 Edisi Desember 2021

turut yaitu sebesar 3,88\% dan 3,93\%, dibawah nilai yang disyaratkan dari Spesifikasi Bina Marga (2010) Revisi 3 (tiga) yaitu nilai rongga dalam campuran (VIM) sebesar 4\%-6\%.

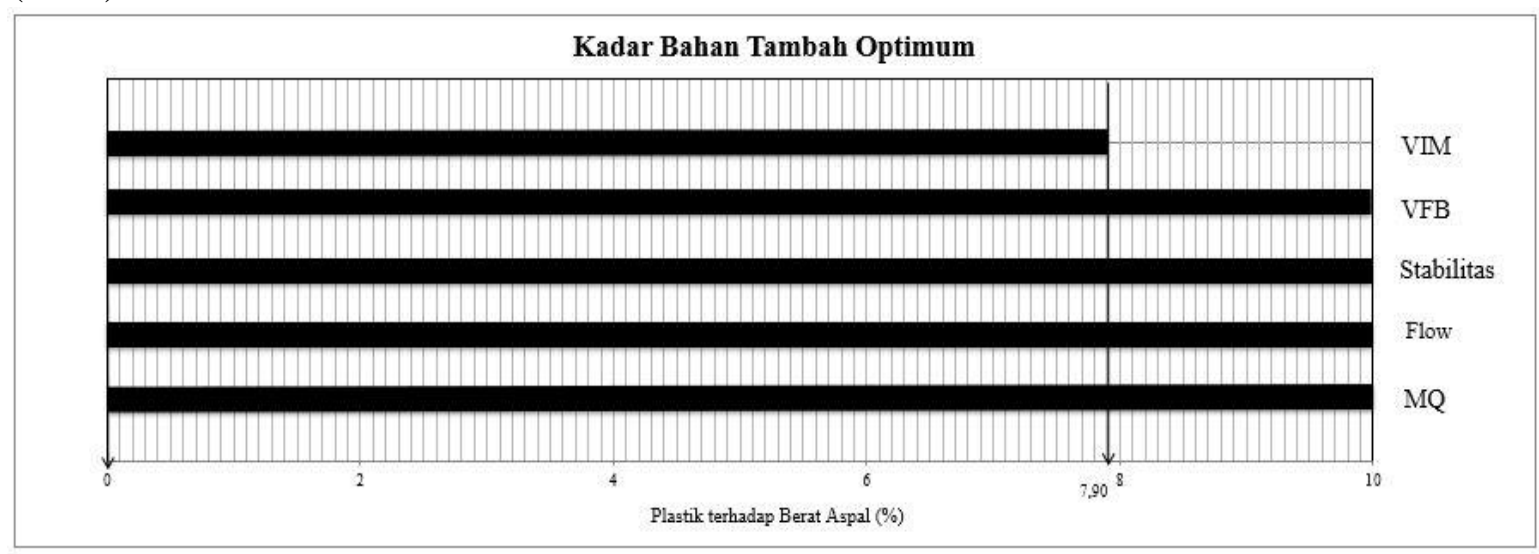

Gambar 4. Grafik Hubungan Nilai Parameter Marshall terhadap Kadar Penambahan Bahan Karet

Hasil evaluasi sifat karakteristik Marshall menunjukan bahwa rentang penambahan kadar karet persentase $0 \%$ hingga 7,80\% campuran memenuhi semua persyaratan yang ditentukan. Berdasarkan rentang tersebut diambil nilai kadar penambahan karet optimum dilihat dari nilai parameter Marshall memenuhi semua persyaratan spesifikasi yang telah ditentukan dan dilihat dari nilai stabilitas tertinggi, yaitu pada kadar penambahan karet sebesar $7,80 \%$ sehingga dapat ditetapkan sebagai kadar bahan tambah optimum. Dari hasil pengujian maka didapat hasil nilai parameter Marshall kadar karet optimum yang bernilai 7,80\% dapat dilihat pada Tabel 10.

Tabel 10. Nilai Parameter Marshall pada Kadar Karet Optimum

\begin{tabular}{|c|c|c|c|c|}
\hline No. & Karakteristik Marshall & Nilai & Persyaratan & Satuan \\
\hline 1 & Stabilitas & 1025 & 800 & $\mathrm{Kg}$ \\
\hline 2 & Flow & 3,42 & $\geq 3$ & $\mathrm{Mm}$ \\
\hline 3 & VIM & 4,10 & $4-6$ & $\%$ \\
\hline 4 & VFB & 80,40 & $\geq 68$ & $\%$ \\
\hline 5 & Hasil Bagi Marshall & 304,00 & $\geq 250$ & $\mathrm{Kg} / \mathrm{mm}$ \\
\hline
\end{tabular}

Sumber: Hasil Perhitungan (2021)

Dapat dilihat dari tabel di atas bahwa nilai parameter karakteristik Marshall dari Kadar Karet Optimum memiliki stabilitas sebesar $1025 \mathrm{~kg}$, flow sebesar 3,42 mm, rongga dalam campuran (VIM) sebesar 4,10\%, rongga terisi aspal (VFB) sebesar 80,40\% dan hasil bagi Marshall (MQ) sebesar $304 \mathrm{~kg} / \mathrm{mm}$.

Dari hasil pengujian, maka dapat dilihat perbandingan parameter karakteristik Marshall antara campuran aspal tanpa menggunakan bahan tambah karet dan yang menggunakan karet sebagai bahan tambah dapat dilihat pada Tabel 11. 
JURNAL KACAPURI

JURNAL KEILMUAN TEKNIK SIPIL

Volume 4 Nomor 2 Edisi Desember 2021

Tabel 11. Perbandingan Nilai Parameter Marshall Campuran Tanpa Karet dan dengan Menggunakan Kadar Penambahan Karet Optimum

\begin{tabular}{|c|c|c|c|c|c|c|}
\hline \multirow[b]{2}{*}{$\begin{array}{l}\text { Komposisi } \\
\text { Campuran }\end{array}$} & \multirow[b]{2}{*}{$\begin{array}{l}\text { Kadar } \\
\text { Karet }\end{array}$} & \multicolumn{5}{|c|}{ Parameter Karakteristik Marshall } \\
\hline & & $\begin{array}{l}\text { Stabilitas } \\
\quad(\mathrm{kg})\end{array}$ & $\begin{array}{l}\text { Flow } \\
(\mathrm{mm})\end{array}$ & $\begin{array}{l}\text { Rongga dalam } \\
\text { Campuran }(\%)\end{array}$ & $\begin{array}{c}\text { Rongga } \\
\text { Terisi } \\
\text { Aspal }(\%)\end{array}$ & $\begin{array}{c}\text { Hasil Bagi } \\
\text { Marshall } \\
\text { (kg/mm) }\end{array}$ \\
\hline $\mathrm{I}$ & 0,00 & 932,00 & 3,15 & 4,90 & 76,20 & 293,00 \\
\hline II & 7,90 & 1025,00 & 3,42 & 4,10 & 80,40 & 304,00 \\
\hline Spesifikasi & - & $>600$ & $>3$ & $4-6$ & $>68$ & $>250$ \\
\hline
\end{tabular}

Sumber: Hasil Perhitungan (2021)

Dari tabel di atas dapat dilihat bahwa penambahan karet sebesar 7,90\% dari berat aspal KAO, nilai stabilitas naik 9,98\% dari nilai stabilitas campuran tanpa menggunakan bahan tambah karet yaitu mengalami kenaikan sebesar $93 \mathrm{~kg}$, nilai flow naik sebesar $0,27 \mathrm{~mm}$, rongga dalam campuran turun sebesar $0,80 \%$, rongga terisi aspal naik sebesar 4,20\% dan hasil bagi Marshall naik sebesar $11 \mathrm{~kg} / \mathrm{mm}$.

\section{PENUTUP}

\section{Kesimpulan}

Setelah melalui serangkaian penelitian yang meliputi pemeriksaan bahan/material, perencanaan benda uji dan pengujian benda uji maka dapat ditarik beberapa kesimpulan yaitu:

1. Agregat Penyusun dalam perencanaan campuran Hot Rolled Sheet Wearing Course (HRS-WC) dari hasil pemeriksaan sifat-sifat fisik agregat berupa pemeriksaan gradasi (analisa saringan), berat jenis dan penyerapan, dan keausan agregat kasar semuanya memenuhi persyaratan spesifikasi.

2. Komposisi yang dihasilkan dalam perencanaan campuran Hot Rolled Sheet Wearing Course terdiri dari 32\% agregat kasar, 34\% abu batu dan 34\% Pasir.

3. Hasil penelitian terhadap Parameter Marshall dengan variasi kadar aspal 6,5\%, 7,0\%, 7,5\%, 8,0\% dan 8,5\% diperoleh Kadar Aspal Optimum (KAO) senilai $7,30 \%$.

4. Hasil penelitian terhadap parameter karakteristik Marshall menggunakan komposisi campuran yang sama dan Kadar Aspal Optimum (KAO) senilai $7,30 \%$ dengan bahan tambah karet padat, variasi kadar bahan tambah karet sebesar 2\%, 4\%, 6\%, 8\% dan 10\% dari berat aspal yang diperoleh dari Kadar Aspal Optimum (KAO), dihasilkan nilai karakteristik parameter Marshall sebagai berikut:

a. Nilai stabilitas untuk semua variasi kadar bahan tambah karet memenuhi spesifikasi yang disyaratkan. Nilai stabilitas tertinggi terdapat pada penambahan kadar karet $10 \%$ yaitu sebesar 1019,803 kg. Nilai Stabilitas yang dihasilkan meningkat seiring dengan penambahan persentase kadar karet.

b. Nilai Kelelehan (flow) untuk semua variasi kadar bahan tambah karet memenuhi spesifikasi yang disyaratkan. Nilai kelelehan (flow) tertinggi terdapat pada penambahan kadar karet $10 \%$ yaitu sebesar 3,48 mm. Nilai flow meningkat seiring dengan penambahan persentase kadar karet.

c. Nilai rongga udara dalam campuran (VIM) untuk variasi kadar bahan tambah karet $2 \%, 4 \%$ dan $6 \%$ memenuhi spesifikasi dan untuk variasi kadar bahan tambah karet $8 \%$ dan $10 \%$ tidak memenuhi spesifikasi. Nilai 
JURNAL KACAPURI

JURNAL KEILMUAN TEKNIK SIPIL

Volume 4 Nomor 2 Edisi Desember 2021

VIM tertinggi yang memenuhi spesifikasi pada kadar penambahan karet $2 \%$, yaitu sebesar $4,92 \%$. Nilai rongga dalam campuran (VIM) yang dihasilkan cenderung menurun dengan penambahan persentase kadar karet.

d. Nilai rongga terisi aspal (VFB) untuk semua variasi kadar bahan tambah karet memenuhi spesifikasi yang disyaratkan. Nilai rongga terisi aspal (VFB) tertinggi terdapat pada penambahan kadar karet $8 \%$ yaitu sebesar $80,91 \%$. Nilai rongga terisi aspal meningkat seiring dengan penambahan persentase kadar karet.

e. Nilai hasil bagi Marshall (Marshall Quotient) untuk semua variasi kadar bahan tambah karet memenuhi spesifikasi yang disyaratkan. Nilai hasil bagi Marshall (Marshall Quotient) tertinggi terdapat pada penambahan kadar karet $8,0 \%$ yaitu sebesar $306,013 \mathrm{~kg} / \mathrm{mm}$ dan nilai terendah terdapat pada penambahan kadar karet $6 \%$ yaitu sebesar $294,698 \mathrm{~kg} / \mathrm{mm}$.

5. Berdasarkan hasil penelitian terhadap parameter karakteristik Marshall dengan variasi kadar bahan tambah karet padat yang sudah dilakukan, dibuat grafik hubungan antara parameter Marshall campuran aspal dengan persentase kadar bahan tambah yang digunakan untuk menentukan nilai kadar karet optimum. Didapatkan kadar penambahan karet optimum sebesar 7,90\%. Nilai parameter karakteristik Marshall pada Kadar Aspal Optimum (KAO) dan penambahan karet pada kadar karet optimum menghasilkan stabilitas sebesar $1025 \mathrm{~kg}$, flow sebesar 3,42 mm, rongga dalam campuran (VIM) sebesar 4,10\%, rongga terisi aspal (VFB) sebesar 80,40\% dan hasil bagi Marshall (MQ) sebesar 304,00 $\mathrm{kg} / \mathrm{mm}$.

6. Penambahan karet padat sebesar 7,90\% dari berat aspal, dapat mempengaruhi parameter karakteristik Marshall nilai stabilitas naik 9,98\% dari nilai stabilitas campuran tanpa menggunakan bahan tambah karet yaitu mengalami kenaikan sebesar $93 \mathrm{~kg}$, nilai flow naik sebesar $0,27 \mathrm{~mm}$, rongga dalam campuran (VIM) turun sebesar $0,80 \%$, rongga terisi aspal (VFB) naik sebesar 4,20\% dan hasil bagi Marshall (Marshall Quotient) naik sebesar 11,00 kg/mm.

\section{Saran}

1. Perlu adanya perlakuan khusus pada karet yang akan ditambahkan pada campuran aspal dan agregat agar sesuai dengan spesifikasi yang digunakan, diharapkan karet dapat tercampur merata untuk menghindari karet menghalangi aspal menyelimuti agregat.

2. Untuk para peneliti lanjut yang tertarik untuk meneliti bahan karet ini disarankan untuk melakukan penelitian pengaruh karet sebagai pengganti aspal.

\section{DAFTAR PUSTAKA}

Arnata, I.W. dan B. Admadi H. 2016. Teknologi Polimer, Bahan Kuliah Fakultas Teknik Universitas Udayana, Denpasar.

Departemen Pekerjaan Umum. 2020. Spesifikasi Umum 2018 Revisi 2, Jakarta.

Darunifah, Nurkhayati. 2007. Pengaruh Bahan Tambah Karet Padat Terhadap Karakteristik Campuran Hot Rolled Sheet Wearing Course (HRS-WC). Tesis Program Pasca Sarjana Universitas Diponegoro, Semarang. 
JURNAL KACAPURI

JURNAL KEILMUAN TEKNIK SIPIL

Volume 4 Nomor 2 Edisi Desember 2021

Satyagraha Fauzi. 2018. Pengaruh Penambahan Limbah Ban dalam Bekas

Kendaraan dan Filler Limbah Karbit pada Laston (AC-BC) Terhadap Karakteristik Marshall. Tugas Akhir Fakultas Teknik Universitas Negeri Yogyakarta. Yogyakarta.

Srikandi. N.N. 2019. Kajian Teknis Penggunaan Karet (Lateks) Sebagai Alternatif Bahan Pengikat Untuk Mengurangi Pemakaian Aspal dalam Campuran Hot Rolled Sheet Wearing Course (HRS-WC). Tugas Akhir Fakultas Teknik Universitas Palangka Raya. Palangka Raya.

Yahya Yusrizal. 2018. Analisis Karakteristik Marshall Campuran Hot Rolled Sheet Wearing Course (HRS-WC) Menggunakan Bahan Tambah Plastik Bekas Jenis Polyethylene Terephthalate (PET). Tugas Akhir Fakultas Teknik Universitas Palangka Raya, Palangka Raya. Palangka Raya 